Praxis International Journal of Social Science and Literature

Impact Factor: SJIF $2020=5.754$ ISSN: 2581-6675

Volume - 4, Issue - 7, July - 2021

Website: www.pijssl.com, E-mail: editor.pijssl@gmail.com

\title{
Understanding Puranic Goddesses of Early Assam
}

\section{Dr. Gargee Sharmah}

Assistant Professor, History Department, Pragjyotish College, Guwahati, Assam. E-mail: gargee.sarma @ gmail.com

\begin{abstract}
The Goddess cult had influenced the socio-religious history of early Assam. Assam was under the influence of Tantra before the Puranic tradition reached the region. Female divinities occupied topmost position in Tantricism. Goddess is central to most of the religious beliefs in ancient Assam, specifically among the local tribal cult. Though the early Vedic literature seldom discussed about the female divinities, the author of the Puranas in later period tried to incorporate the regional goddesses to Puranic literature due to their popularity among the local people. The authors of the Puranas tried to spread Brahmonical social order and therefore choose the popular goddesses. Some Mahapuranas and Upa-Puranas richly equipped with Mother cult. This paper intends to discuss the status of some Puranic goddesses of early Assam with the help of sculptural evidences.
\end{abstract}

Keywords: Goddess, Mahapurana, Upa-Purana, Sculpture, Tantra, Mother cult, Vedic literature

\section{Introduction}

Mother Goddess played an important role in the religious history of Assam. Both literature and archaeology have proved that Assam was a stronghold of Mother cult and it had shaped the cultural history of the region. Before Puranic Brahmanism reached Assam, the region was under the influence of Tantric religion. In Tantricism female divinities occupied the dominating position ${ }^{1}$. Therefore, worship of Devi had remote antiquity in Assam. The early Vedic literature rarely discuss about goddesses. But the Pranakaras gave much stress on female divinities. Under the Gupta regime, Puranic religious practices and beliefs spread. Bengal was annexed to the Gupta Empire around the fifth century A.D. From the study of Allahabad Pillar Inscription, it is clear that early Assam was also under the influenced of the Guptas during the rule of Samudragupta. Puranic literature is richly equipped with the references of female divinities and it becomes important to trace the Goddess concept in some of the Mahapuranas and Upa-Puranas (Minor
Puranas). It is important to note that the Puranakaras elaborately discussed many myths connected with Siva, Parvati and Sakta pithas (seat for Sakti). A number of tribal and regional female divinities were depicted as the manifestation of Aryan Goddess Durga with the help of the Daksa Yajna ${ }^{2}$ story. Most of the Puranakaras believed that Kamarupa (ancient Assam) is the most important seat of Devi (Goddess) as genital organ of Sati fell on this land.

\section{Objective}

The objective of the paper is to analyze the status of some female divinities of early Assam in the light of Puranic literature with the help of sculptural evidence.

\section{Discussion}

In the context of early Assam, Kamakhya is the most dominating name in the Kalika Purana. It reflects the religious life of the people. Kalika 
Purana was one of the important Upa-Purana composed in Kamarupa (ancient Assam) probably in tenth century A.D. or first half of eleventh century A.D. The chief goddess of the text, Kamamkya, is a local deity of Kamarupa. She is not portrait as a war goddess. The main aim of the text is to praise the glory of Kamakhya. Kamarupa was better known as a land of magic because of its association with Tantric shrine of Kamakhya. Both literature and archaeology suggest the prevalence of Sakti cult in Assam from very early period. Kalika Purana describes a story how the genital organ of Sati fell at Nilachala hillock when her husband Siva carried her dead body. Till present day yoni (genital organ) symbol is worshipped in Kamakhya temple (Guwahati). The text also narrates that Naraka had driven the aboriginal Kirata inhabitants from Kamarupa and settled Aryan people and he became the custodian of the yoni goddess Kamakhya. According to Banikanta Kakati it was under the banner of Mother Goddess Kamakhya that the first empire of early Assam was built ${ }^{3}$.

The Markandeya Purana is one of the important Mahapuranas. Its Devimahatmya section is one of the most important text of Goddess worship. In this text almost all the forms of Devi are primarily conceived as war goddesses who only confer victory and success on her devotees in the battle field ${ }^{4}$. The main goddess of Devimahatmya, Candika, is the goddess of war. She took various forms at various crucial moments to destroy demons who gave formidable challenges to the gods of heaven. Mahisamardini (goddess killing the demon Mahisa) is one of the earliest and important aspects of Devi in the Devimahatmya section of the Markandeya Purana. Here Goddess Ambika is equated with Candika. Devi is identified with Prakriti and has both ugra (fearful) and santa (benign) form. Mahishamardini, the ugra form of Goddess Durga, is the most important and popular form. The Devimahatmya section gives the description of Mahishamardini Durga in great detail. This form of goddess Durga is most popular in India, particularly in Eastern India including Assam. A large number of images of Mahishamardini
Durga, rock-cut as well as carved on stone slabs, are found in Assam. Mahishamardini had different names according to the number of her hands. The ten-handed image is called Katyayani and eighteen-handed image is called Ugrachanda according to Matsya Purana and Agni Purana 5. In Sirajuli,( in Sonitpur district of Assam) an image of Mahishamardini is found which is carved on a stone-slab,is now preserved in a private house of Dhekiajuli town ${ }^{6}$. This goddess has ten arms. A very interesting eighteen-handed Mahishamardini was found in Uzanbazar area of Guwahati, was beautifully carved on a rock. An eighteen-handed Mahishamardini in the form of Ugrachanda is very rare in early Assam. Therefore, the image is of high iconographic significance. One rare image of sixteen-handed Mahishamardini is found from Ambari (Guwahati) site. This image is made of clay stone. The pedestal bears an inscription which has identified her as 'Candanayika'. Kalika Purana mentioned Candanayika as one of the eight Saktis of the Great Goddess. In the Agni Purana and the Bhavisya Purana Candanayika is described under the collective designation of Nava-Durga. Inscribed goddess image is rare in Assam. Therefore, this image has great significance. A large number of Mahishamardini images found from different places of Assam such as Hajo, Kamakhya, Singari, Bamuni Pahar, Charduar, Bhoi Parbat, Ambari prove the popularity of the Puranic goddess in early Assam

Matsya Purana, an earlier generation Purana, relates the goddess with two great mountains .The Mountain Himalayas depicted as the father of Goddess Parvati and mountain Vindhya is depicted to as her abode ${ }^{7}$. Matsya Purana also narrates the story of the origin of the goddess Kali. Fearful aspect of Bhadrakali also portrays by the text. It is mentioned in this Purana that Kali is a nickname of Goddess Parvati. Another fearful Goddess Kaushiki is born out of Parvati. All these goddesses such as Kali, Bhadrakali, Parvati, mentioned by this Purana were known to the people of ancient Assam which is proved by sculptural evidences. A composite figure called Ardhanariswara emerges in this 
Purana. This image combined Siva and Sakti in one body. It is generally thought that Ardhanariswara symbolises a syncretistic attitude of the two principal rival sects, such as Saivas and Saktas. This combined form is common in early Assam. It is evident from the Khanamukh and Subhankarapataka grant of Dharmapala ${ }^{8}$ in each of these two inscriptions the first verse invokes the god under the name of ardhayuvatiswara. One Ardhanariswara image is found from Mathorbari in Nagaon district. The right half represents the god Siva and the left represents the Goddess Sakti. Respective vehicles of the divinities, bull and lion are visible ${ }^{9}$.

Some of the early Puranic literature viz Vishnu Purana, Bhagavata Purana, Brahmanda Purana and Matsya Purana were completed in the Gupta period. The Brahma Purana, probably the earliest among the Puranas, describs the placid aspects of the goddess. It mentions the burning of Sati, daughter of Himalaya ${ }^{10}$ and wife of Siva. This goddess is also called Uma in one of her manifestation. Large numbers of sculptures of the placid aspects of goddess prove that this form of goddess was popular in Assam from very early period. It is interesting that though the Bhagavata Purana is a gospel of Vaisnavas text, it also deals the worship of Sakti.

The Visnu Purana is a purely sectarian text of the Vaisnavites. However, the text eulogises Sakti as essence of all that exist. This text mentions various names of the goddess like Ambika, Durga, Arya Bhadrakali etc. The goddess is described as fond of meat and wine which suggest Tantric characteristics feature. From the appellation Mahisasuramardini it is clear that the concept of the goddess who killed the demon Mahisha was known to the author of the Vishnu Purana. It is already discussed with the help of sculptural evidences that the Puranic goddess Mahishamardini occupied prominent place in the religious history of early Assam.

The Agni Purana in the Puranic literature is very important text for iconographic study. It deals in full details with the Devi Pratimas ${ }^{11}$. This text referred to several techniques which were used for the making of image of goddesses. Agni Purana mentions that goddess Candika should be represented as having twenty hands, each holding various weapons like trident, sword, spear, axe, bow, bell, banner etc. Different names of Durga images have been referred in this Purana where Camunda is also included. Goddess Camunda was known to the people Assam from early period which is proved by sculptural studies. Goddess Camunda is described as terrible in appearance: she is gaunt, has fangs, laughs loudly, dances madly, wears a garland of corpses, sits on the back of a ghost and lives in a cremation ground. It describes the image of the goddess with sunken eyes, thin belly, fleshless skeleton body upward hairs, holding skull and a skin of tiger in her left and trident and axe in her right hand ${ }^{12}$. A six handed image of Camunda is founded at Nabhanga, five miles away from Hojai railway station in the Nagaon district of Assam. The image is carved on black stone. The image has an awful appearance. The body is emaciated, the bones of the chest are exposed, eyes are sunk into their sockets, abdomen is shriveled and the mouth is open. Human heads are laced around the hairlock, the waist and also the neck. The image is half-seated upon a dead body. In the pedestal on the right side is a vulture and in the left, a jackal. Bhattacharjee approximates the image to tenth/eleventh century A.D ${ }^{13}$. Several sculptures of Camunda from different places of Assam such as Kamakhya, Barpathar etc. (which belonged to the period from eight to twelfth century C.E.) prove that this goddess was known in Assam from a very early period ${ }^{14}$.

Vayu Purana describes that Uma was born to Menaka. She is described as Rudrani who was born at the request of Siva ${ }^{15}$ to safeguard the Brahmanas. Goddess Uma is known in the religion of Assam. An interesting figure of Uma with Maheswara is found from Dabaka which is roughly approximated to ninth-tenth century C. $E^{16}$. Some other figures of Uma and Maheswara are found from Tezpur, Barganga, Deopani of Assam prove that Uma was a common deity in Assam. 
In Brahmavaivarta Purana some prominent local goddesses like Manasa, Sasthi, Kali Candika, Mangala-Candi got recognition. In Assam snake cult has been widely prevalent. It is proved by a few images of snake goddess Manasa. One standing image of the goddess is found at Silghat in Nagaon District of Assam which probably belong to the eleventh century A.D ${ }^{17}$. Two images of Manasa are found from the Narakasur ruins. One image is found in Guwahati and now preserved in Assam State Museum. A very interesting image of Manasa is found in a tea garden near Kaliabar, Nagaon district of Assam. The vehicle of the deity is an elephant which is an exception.

The Varaha Purana (eighth to eleventh century A.D. $)^{18}$ depicts mainly a fearful goddess that we find in Devimahatmya. Devi Purana mainly discusses the exploits of Devi, who incarnated herself in the Vindhyas and was known as Vindhyavasini ${ }^{19}$. It deals with different forms of the Goddess such as Ambika, Kali, Uma, Durga, Sakambhari, Vindhyavasini, Kausiki, Narayani, Laksmi, Saraswati, Katyayani etc. Devi Purana also refers to some composite deities as Uma-Mahesvara, Hari-Hara and Ardhanarisvara. We have already mentioned about the sculptural findings of Ardhanariswara and Uma Maheswara. Hari-Hara, the important syncretistic deity, is also

\section{Notes and Reference}

1. Chakrabarty, K. (2011). Cult Region: The Puranas and Making of the Cultural Territory of Bengal in Singh, U. (ed)., Rethinking Early Medieval India, Oxford University Press, Delhi, p. 235

2. According to various Puranic text Sati(wife of Siva) being unable to tolerate her husband's insult by her father Daksa, left her mortal coil at the place of sacrifice arranged by the latter. Siva out of anger moved frantically with Sati's dead body upon his shoulder. There was earthquake and the destruction was imminent. To make Siva quiet, Visnu cut with his Sudarshana Cakra Sati's popular in early Assam. This composite image unites two rival cults Saiva and Vaishnavas. Two Hari-Hara images from Deopani and one rare image of Hari-Hara preserved in Assam State Museum prove that Hari- Hara was a known deity in Assam. It is interesting that in Devi Purana the female deities are much powerful then the Puranic god.

Mahabhagavata Purana is an Upa-Purana which deals with the praise of Goddess and her worship ${ }^{20}$. This text opens with four Mangala slokas, containing the salutations of Devi. Mahabhagavata Purana mainly deals with the praise of Devi, her incarnations to destroy the demons, their exploits, praise of Kamarupa and fifty-one pithas of Devi.

\section{Conclusion}

From the study of archaeology and literature it is clear that Assam was a centre of Devi worship from very early period. Even before the Puranic Brahbanism reached the region, female divinities played an important role in the religion of Assam. The Puranakaras choose the goddess because of their popularity among the local tribal people. By twelfth century A.D. female divinities in different forms with different names gained popularity in Assam

lifeless body into pieces. The severed parts of Sati's body fell on the earth and each formed a pitha. It is believed that Mother Goddess lived with her consort Siva in such places assuming different names.

3. Kakati, B. (1989). The Mother Goddess

Kamakhya, Publication Board of Assam, Guwahati, p.1

4. Sharmah, G. (2020). Mother Goddess Cult in

Eastern India, Bishal Prakashan, Guwahati, p. 44 
5. Barpujari, H.K. (1990). The Comprehensive History of Assam, Vol. I, Publication Board of Assam, Guwahati, p. 368.

6. Choudhuri, N.D. (1992). The Goddess Mahishamardini and her Icons in Assam in The Journal of The Assam Research Society, Vol. xxxii, Guwahati, p.31

7. Agarwala, V.S.( 1963) Matsya Purana-A study, Varanasi, p. 245

8. Sarma, D.(ed.). (2003). Kamarupasasanavali, Publication Board Assam, second edition, Guwahati, pp. 214-221

9. Barpujari, H.K. (1990). The Comprehensive History of Assam, Vol. I, Publication Board of Assam, Guwahati,

10. In the Puranas Mother Goddess is sometimes associated with mountains like Himalaya, Vindhya etc.Thus Goddesses like Vindhyavasini, Himasailaja, Girija, Parvati are popular in the Puranas. Most probably earlier they were worshipped by the non-Aryan people who lived in the hills and forest. Chattopadhyaya, S., Evolution of Hindu Sects: Up to the Time of Sankaracharya, Munshiram Manoharlal. New Delhi, 1970,.p. 101102, also see Srivastava, M.C.P., Mother Goddess in Art, Archaeology and Literature, Agam Kla Prakasan, New Delhi, 1979, p. 109.

11. Agni Purana, Chapters 50,52,94.

12. Agni Purana, 50/21-23

13. Bhattacharjee,A, Icons and sculptures of Early and Medieval Assam, Inter-Indian Publication, Delhi, p.30.

14. Sharmah, G. (2020). Mother Goddess Cult in Eastern India, Bishal Prakashan, Guwahati, pp.

127-128

15. Vayu Purana, 72/16- 20.

16. Choudhury, R.D. (1998,). Catalogue of Stone Sculptures - Assam State museum, Directorate of Museums, Guwahati, p.15
17. Choudhury, R.D. (1998) Catalogue of Stone Sculptures - Assam State museum, Directorate of Museums, Guwahati, p.30.

18. Hazra, R.C., (1987). Puranic Records on Hindu Rites and Customs, Delhi,(reprint), pp. 106-106.

19. The association of the Goddess with the Vindhya region is interesting. S.Chattopadhyaya in his work mentions that this range was the home of various Proto-Austroloid tribes while elsewhere the goddess is expressedly associated the Sabaras and Pulindas who lived in the same range. The description clearly showes that a Mother Goddess of the Proto-Austrolod tribes was now being merged with the great Aryan Mother Goddess. Chattopadhyaya, S., Evolution of Hindu Sects: Up to the Time of Sankaracharya, Munshiram Manoharlal. New Delhi, 1970,.p. 101-102.

20. Hazra, R.C., op. cit., p.261. 